\title{
Article
}

\section{Water quality, feeding management and cost-benefit analysis of a fish hatchery in Jessore district of Bangladesh}

Md. Monirul Islam ${ }^{1} *$, Rashidul Hassan ${ }^{1}$, B.M. Newaz Sharif ${ }^{1}$, Md. Mostafizur Rahaman ${ }^{1}$, Md. Aminur Islam ${ }^{2}$ and Md. Ruhul Amin ${ }^{1}$

${ }^{1}$ Department of Aquaculture, Faculty of Fisheries, Bangladesh Agricultural University, Mymensingh-2202, Bangladesh

${ }^{2}$ Department of Fisheries Biology and Genetics, Faculty of Fisheries, Bangladesh Agricultural University, Mymensingh-2202, Bangladesh

*Corresponding author: Md. Monirul Islam, Department of Aquaculture, Faculty of Fisheries, Bangladesh Agricultural University, Mymensingh-2202, Bangladesh. Phone: +8801842090423; E-mail: monirul.jstu@gmail.com

Received: 01 September 2016/Accepted: 20 September 2016/ Published: 29 September 2016

\begin{abstract}
The study was conducted at Ma-Fatema Fish Hatchery in Jessore from January to March, 2016. The present study was emphasized on water quality parameters, feeding management and cost- benefit analysis. The water quality parameters temperature $\left({ }^{0} \mathrm{C}\right), \mathrm{pH}$, dissolved oxygen $(\mathrm{DO})(\mathrm{mg} / \mathrm{l})$ and transparency $(\mathrm{cm})$ were measured by Celsius thermometer, $\mathrm{pH}$ meter, DO meter and secchi disk, respectively. The proximate composition of feed ingredients was determined by the Association of Analytical Chemists, 1980. Brood fishes were reared all year round in the brood ponds by supplying formulated feeds. Temperature was $19^{\circ} \mathrm{C}-26^{\circ} \mathrm{C}$ in brood ponds and $18^{\circ} \mathrm{C}-24^{\circ} \mathrm{C}$ in hatching jars; $\mathrm{pH}$ was $6.93-7.87$ in brood ponds and 6.79-7.54 in the hatching jars; dissolved oxygen was 4.8-6.3 mg/l in brood ponds and 4.8-6.7 mg/l in hatching jars; transparency was 14$18 \mathrm{~cm}$ in the brood ponds. The percentage of farm made feed was protein (27.76\%), lipid (4.9\%), $\mathrm{CHO}$ (18.62\%), ash (11.31\%), fiber (6.4\%), moisture (31.01\%). The cost benefit ratios were 1.54, 1.32 and 1.23 and net profits were BDT 49911.67, BDT 24816.67and BDT 16366.67 respectively in January, February and March. Management of brood fish by providing quality feed and physico-chemical parameters of water were maintained in according to scientific procedure. Cost-benefit ratio of the hatchery in common carp production was satisfactory.
\end{abstract}

Keywords: water quality parameters; proximate composition of the formulated feed; cost-benefit analysis; hatchling production

\section{Introduction}

Aquaculture practices in Bangladesh started with natural seed but now it is almost entirely (99.55\%) replaced by hatchery produced seed. Supply of fingerlings is a prerequisite for the development of aquaculture (Webber and Riordan, 1976). There are 882 (790 are private and 92 are government) fish hatcheries produced carp hatchlings and 10802 fish nurseries are operating in Bangladesh (DoF, 2014). Physicochemical characteristics such as dissolved oxygen, temperature, $\mathrm{pH}$, hardness, nitrite and mineral content must be considered in the selection of suitable sources and important for the production of higher quality and healthy fish. Water pH plays an important role in the metabolism and physiology of aquatic animals (Parra and Baldisserotto, 2007). Extreme $\mathrm{pH}$ values negatively affect fish growth and reproduction (Zweig et al., 1999).Extremely acidic $\mathrm{pH}$ causes degeneration of gill tissue and increased mucus production, which can kill fish by asphyxia (Boyd, 1990). In extremely alkaline water, however, immediate inhibition of ammonia excretion can occur, causing a potentially lethal increase in plasma levels (Wilkie and Wood, 1994). Over the last two decades, Jessore district has 
experienced an intense growth of fish breeding hatcheries than any other parts of Bangladesh (Samad et al., 2013). Feeding management is very important in brood fish rearing in fish hatchery. Supply of artificial feeds along with natural foods have been a common practice at hatchery in Bangladesh. Calculation of economic analysis is an important aspect of any hatchery operation. Thus it is important to get an idea about the present status of hatchery management in Jessore to analyze the proximate composition of brood rearing feed, to know the water quality parameter and estimate cost benefit analysis of the hatchery produced spawn.

\section{Materials and Methods}

\subsection{Study area and duration}

The experiment was conducted in a private hatchery named as "Ma-Fatema Fish Hatchery" Chanchra, Jessore from January, 2016 to March, 2016.

\subsection{Feed formulation}

Formulated farm made feeds were used for rearing of brood fish. Fish meal, soybean meal, mustard oil cake, rice bran, wheat bran, wheat flour, vitamin premix were used for the preparation of feed (Table 1).

Table 1. Ingredients of formulated feed.

\begin{tabular}{ll}
\hline Feed ingredients & Amount (\%) \\
\hline Rice bran & 30 \\
Wheat bran & 20 \\
Mustard oil cake & 13 \\
Soybean meal & 12 \\
Fish meal & 10 \\
Corn meal & 10 \\
Molasses, salt & 2 \\
Vitamin, Di-calcium phosphate & 3 \\
\hline Total & $\mathbf{1 0 0}$ \\
\hline
\end{tabular}

\subsection{Feeding management of brood fish}

The brood fish were fed twice a day morning and evening. In first few days, feeds were applied at the rate of 2$3 \%$ of the body weight according to the feeding requirement of the fish.

\subsection{Physicochemical parameters of hatchery water}

Maintenance of water quality parameters is very important for hatchery management. Poor quality water increases the chance of pathogenic and parasitic infection to the fish. The quality of fish seed depends on the quality of water.

\subsubsection{Collection of water sample}

The water samples were collected from the hatchery brood ponds. For collecting water sample at first two 250 $\mathrm{ml}$ plastic bottles were collected. Then bottles were washed well with clean water for 3 to 4 times. Then the outside of each bottle was covered with black plastic tape to avoid the chemical change due to sunlight. Water samples were collected just before the eggs released in to the incubation tank.

\subsubsection{Water temperature $\left({ }^{\circ} \mathrm{C}\right)$}

Water temperature was measured at 7 days interval in brood ponds and 2 days interval in incubation tank during the study period. Temperature was measured by a Celsius thermometer.

\subsection{3. $\mathrm{pH}$}

$\mathrm{pH}$ of the water was recorded at 7 days interval in brood ponds and 2 days interval in incubation tank during the study period. The water $\mathrm{pH}$ was measured by using $\mathrm{pH}$ meter (EZODO $\mathrm{pH}$ Model 7200).

\subsubsection{Dissolved oxygen (mg/L)}

The dissolved oxygen value was recorded at 7 days interval in brood ponds and 2 days interval in incubation tank during the study period. Dissolved oxygen value was recorded by using a dissolved oxygen (DO) meter (Lutron, YK 22 DO). 


\subsubsection{Transparency $(\mathrm{cm})$}

The water transparency was recorded at 7 days interval in brood ponds by using secchi disk ( $15 \mathrm{~cm}$ diameter) and measuring tape.

\subsection{Analysis of proximate composition of feed}

The proximate composition of feed ingredients was determined following the methods of Association of Analytical Chemists (AOAC, 1980). Analysis was done in the Fish Nutrition Laboratory, Department of Aquaculture, Bangladesh Agricultural University, Mymensingh.

\subsubsection{Estimation of crude protein}

Crude protein content was quantified by the standard micro-Kjeldahl nitrogen method using a BehrosetInKje $\mathrm{M}$ digestion apparatus and Behr S I steam distillation apparatus (both Labor -Technik GmbH, Dusseldrof, Germany). Calculations of crude protein of the samples were done using the following formula,

Where,

$$
\% \text { Nitrogen }=\frac{\text { Miliequivalent of Nitrigen } \times \text { Stength of HCL } \times \text { Tirant used }}{\text { Weight of sampe }(\mathrm{g})} \times 100
$$

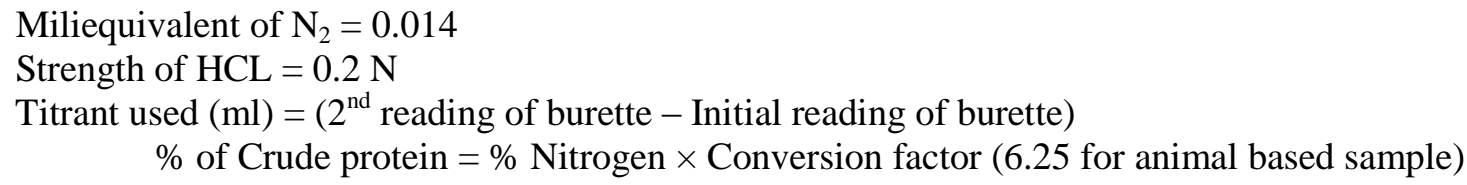

\subsection{Estimation of crude lipid}

Crude lipid content was analyzed by drying the samples in oven at $105^{\circ} \mathrm{C}$ and then extracting the fat with acetone in a Soxhlet Extractor for 4 hours. Calculation of lipid was done by using the following formula (according to AOAC method):

$$
\% \text { Crude lipid }=\frac{\text { Wt. of beaker with lipid after oven dry }- \text { initial wt. of beaker }}{\text { Weight of sample }} \times 100
$$

\subsubsection{Estimation of carbohydrate (CHO)}

Carbohydrate content of the samples was determined as total carbohydrate by difference that is, subtracting the measured protein, fat, ash and moisture from 100 (Pearson, 1976).

\subsubsection{Estimation of moisture content}

Moisture content refers to the total amount of water present in the sample was measured by weighing differences before and after oven drying at $105^{\circ} \mathrm{C}$ for 24 hours. The percentage of moisture content was calculated by following formula:

Where,

$$
\% \text { Moisture content }=\frac{\mathrm{Y}-\mathrm{Z}}{\mathrm{S}} \times 100
$$

$\mathrm{S}=$ Weight of sample before drying $(\mathrm{g})$

$\mathrm{Y}=$ Weight of crucible with sample $(\mathrm{g})$

$\mathrm{Z}=$ Weight of crucible with dry sample $(\mathrm{g})$

\subsubsection{Estimation of ash}

Ash content was determined using dry ashing procedures. Empty porcelain crucibles were marked and weighted by electronic balance, for each sample 3 replicate crucibles were taken. About 2-3gm of sample taken in each crucible by weighing electronic balance. Then the crucibles were placed in a muffle furnace at $550^{\circ} \mathrm{C}$ for 6 hours. After 6 hours the muffle furnace was stopped over night rest. When the muffle furnace became cool the door was open and the crucibles were taken out by using spatula. The sample was weighed separately using same electronic balance, the data were tabulated in a table and percentage (\%) of ash content was calculated from the data by following formula:

$$
(\%) \text { of Ash content }=\frac{(\text { Dry sample }+ \text { crucible })-\text { empty crucible }}{\text { Weight of sample }} \times 100
$$




\subsubsection{Estimation of crude fiber}

The percent of crude fiber content was calculated by using following formula:

$$
\% \text { Crude of fiber }=\frac{\text { Weight before ashing }(\mathrm{g})-\text { Weight after ashing }(\mathrm{g})}{\text { Weight of sample }(\mathrm{g})} \times 100
$$

\subsection{Statistical analysis}

The results obtained in the experiment were subjected to analysis. Qualitative and quantitative analysis of all kinds of data were carried out. Microsoft Office Excel 2007 was also used for presentation of the tables and graphs obtainable from different types of data.

\subsection{Cost-benefit analysis}

Calculation of cost-benefit analysis is an important aspect of any hatchery operation. The cost benefit analysis of 'Ma-Fatema Fish Hatchery' was done. The capital cost, operating cost, revenue income, cost-benefit ratio and net profit were analyzed based on the common carp hatchling production.

\subsubsection{Capital cost}

A capital cost means the costs during the hatchery construction and set up.

\subsubsection{Operating cost}

The operating cost refers to costs involved to run the hatchery operation e.g. labour, feed, PG etc.

\subsubsection{Depreciation cost}

Annual depreciation cost was calculated by using the following formula (Akhter, 2007).

$$
\text { Annual depreciation }=\frac{\text { capital cost }}{\text { project life }}
$$

\subsubsection{Total cost}

Total cost was calculated by using the following formula (Akhter, 2007).

Total cost $=$ Operating cost + Depreciation cost

\subsubsection{Revenue income}

The revenue income is the total sale of hatchling during experimental period.

\subsubsection{Cost benefit ratio}

Total cost benefit ratio was calculated by using the following formula:

$$
\text { Cost benefit ratio }=\frac{\text { Total benefit }}{\text { Operating cost }}
$$

\section{Results}

\subsection{Water quality parameters}

The water quality parameters like temperature $\left({ }^{\circ} \mathrm{C}\right), \mathrm{pH}$, dissolved oxygen $(\mathrm{mg} / \mathrm{l})$ and transparency $(\mathrm{cm})$ were monitored during the study period (January to March, 2016).

\subsubsection{Temperature $\left({ }^{\circ} \mathrm{C}\right)$}

In the brood ponds, water temperature ranged from $19^{\circ} \mathrm{C}-26.0^{\circ} \mathrm{C}$ during the study period. The maximum water temperature was $26.0^{\circ} \mathrm{C}$ in $6^{\text {th }}$ week and minimum was $19.0^{\circ} \mathrm{C}$ in $1^{\text {st }}$ week. In the hatching jars, maximum water temperature was $25.0^{\circ} \mathrm{C}$ in the $6^{\text {th }}$ week and minimum were $18.0^{\circ} \mathrm{C}$ in the $1^{\text {st }}$ week (Figure1).

\subsection{2. pH}

In the brood ponds, $\mathrm{pH}$ ranged $6.93-7.87$ during the study period. The maximum $\mathrm{pH}$ was 7.87 in $2^{\text {nd }}$ week and minimum was 6.93 in $4^{\text {th }}$ week. In the hatching jars, maximum $\mathrm{pH}$ was 7.54 in the $3^{\text {rd }}$ week and minimum was 6.79 in the $1^{\text {st }}$ week (Figure 2). 


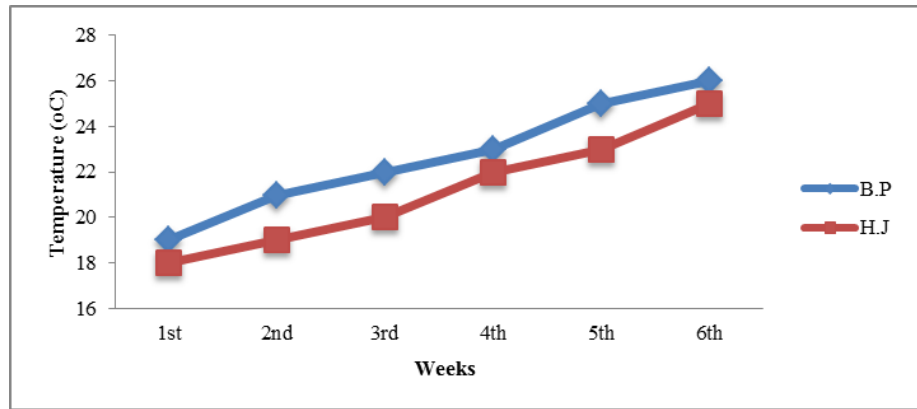

Figure 1. Weekly variation of temperature $\left({ }^{0} \mathrm{C}\right)$ in brood ponds $(\mathrm{B} . \mathrm{P})$ and hatching jars (H.J).

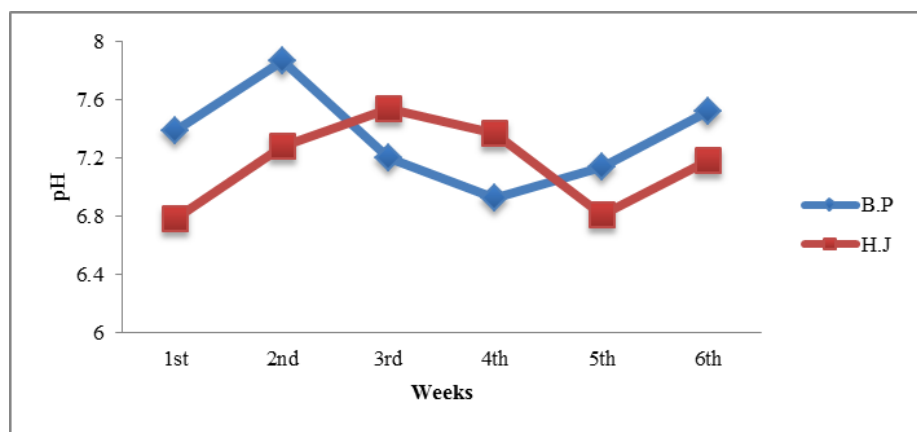

Figure 2. Weekly variation of pH in brood ponds (B.P) and hatching jars (H.J).

\subsubsection{Dissolved oxygen $(\mathrm{mg} / \mathrm{L})$}

In the brood ponds, dissolved oxygen ranged $4.8-6.3 \mathrm{mg} / \mathrm{l}$ during the study period. The maximum dissolved oxygen was $6.3 \mathrm{mg} / \mathrm{l}$ in $3^{\text {rd }}$ week and minimum was $4.8 \mathrm{mg} / \mathrm{l}$ in $2^{\text {nd }}$ week. In the hatching jars, maximum DO was $6.7 \mathrm{mg} / \mathrm{l}$ in the $4^{\text {th }}$ week and minimum was $4.8 \mathrm{mg} / \mathrm{l}$ in the $6^{\text {th }}$ week (Figure 3 ).

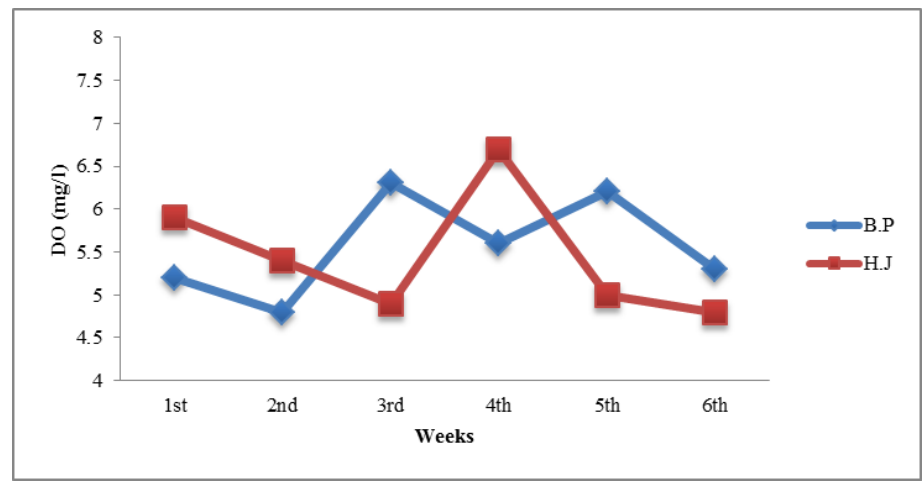

Figure 3. Weekly variation of DO (mg/l) in brood ponds (B.P) and hatching jars (H.J).

\subsubsection{Transparency $(\mathbf{c m})$}

Transparency varied from 14 to $18 \mathrm{~cm}$. in different ponds during study period. In brood ponds the highest transparency was $18 \mathrm{~cm}$ in $6^{\text {th }}$ week and lowest transparency was $14 \mathrm{~cm}$ in $3^{\text {rd }}$ week (Figure 4).

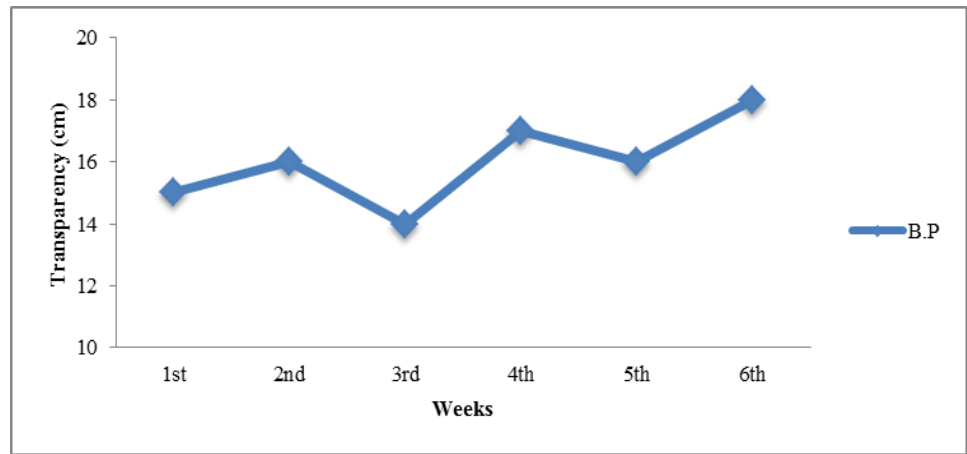

Figure 4. Weekly variation of Transparency $(\mathrm{cm})$ in brood ponds (B.P). 


\subsection{Proximate composition}

Proximate composition of the formulated feed used for rearing of brood fish as shown in figure 5.

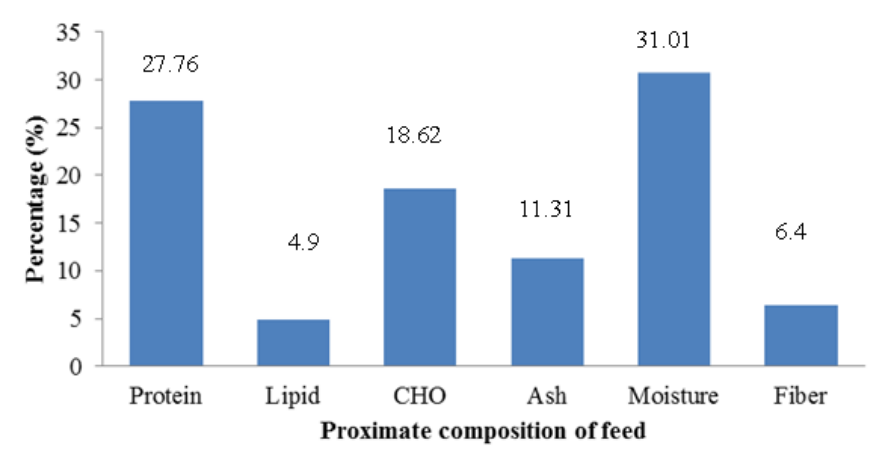

Figure 5. Proximate composition of the formulated feed used for rearing of brood fish.

\subsection{Cost- benefit analysis}

The capital cost, operating cost, total cost, hatchling production, price of hatchling, revenue income and net profit were analyzed respectively, based on the common carp hatchling production as shown in (Tables 2 to 8 ).

Table 2. Capital cost.

\begin{tabular}{ll}
\hline Items & Estimated cost (BDT) \\
\hline Land & 600000 \\
Hatchery pipelines & 150000 \\
Pond construction & 210000 \\
Hatchery building & 800000 \\
Brood fish & 80000 \\
Drainage system & 100000 \\
Pump house & 160000 \\
Deep tube well & 200000 \\
Electricity & 50000 \\
Equipments & 40000 \\
Generators & 60000 \\
Road & 20000 \\
Miscellaneous & 10000 \\
\hline Total & $\mathbf{2 4 8 0 0 0 0}$ \\
\hline
\end{tabular}

\subsubsection{Depreciation cost}

$$
\begin{gathered}
\text { Annual depreciation cost }(\mathrm{BDT})=\frac{\text { capital cost }}{\text { project life }}=\frac{2480000}{50}=49600 \\
\text { Monthly depreciation cost }(\mathrm{BDT})=\frac{49600}{12}=4133.33
\end{gathered}
$$

Table 3. Operating cost.

\begin{tabular}{llll}
\hline Items & $\begin{array}{l}\text { Estimated cost }(\text { BDT) in } \\
\text { January }\end{array}$ & $\begin{array}{l}\text { Estimated cost (BDT) in } \\
\text { February }\end{array}$ & $\begin{array}{l}\text { Estimated cost (BDT) in } \\
\text { March }\end{array}$ \\
\hline Labor salary & 35000 & 30000 & 28000 \\
Feed (brood) & 35000 & 35000 & 35000 \\
Feed (fry) & 1000 & 1000 & 1000 \\
Fertilizer & 6000 & 5000 & 4000 \\
Electricity & 5000 & 5000 & 6000 \\
Medicine & 2000 & 1500 & 1000 \\
Selling cost & 1000 & 1000 & 1000 \\
Netting cost & 2500 & 2000 & 2000 \\
PG & 10055 & 8050 & 6000 \\
Security & 2000 & 2000 & 2000 \\
Miscellaneous & 1000 & 1000 & 1000 \\
\hline Total & $\mathbf{1 0 0 5 5 5}$ & $\mathbf{9 1 5 5 0}$ & $\mathbf{8 7 0 0 0}$ \\
\hline
\end{tabular}


Table 4. Total cost.

\begin{tabular}{lll}
\hline Month & Operating cost + Monthly depreciation cost (BDT) & Total cost (BDT) \\
\hline January & $100555+4133.33$ & 104688.33 \\
February & $91550+4133.33$ & 95683.33 \\
March & $87000+4133.33$ & 91133.33 \\
\hline & Grand total cost & $=\mathbf{2 9 1 5 0 4 . 9 9}$ \\
\hline
\end{tabular}

Table 5. Hatchling production (kg).

\begin{tabular}{llll}
\hline Species & January $(\mathbf{k g})$ & February (kg) & March (kg) \\
\hline Scale carp & 27 & 28 & 25 \\
Mirror carp & 10 & 8 & 10 \\
Leather carp & 8 & 5 & 3 \\
\hline Total production $(\mathbf{k g})$ & $\mathbf{4 5}$ & $\mathbf{4 1}$ & $\mathbf{3 8}$ \\
\hline
\end{tabular}

Table 6. Price of hatchling.

\begin{tabular}{llll}
\hline Species & January (BDT)/kg & February (BDT)/kg & March (BDT)/kg \\
\hline Scale carp & 3000 & 3000 & 3000 \\
Mirror carp & 3000 & 3000 & 2500 \\
Leather carp & 2800 & 2500 & 2500 \\
\hline
\end{tabular}

Table 7. Revenue income.

\begin{tabular}{llll}
\hline Species & January (BDT) & February (BDT) & March (BDT) \\
\hline Scale carp & 81000 & 84000 & 75000 \\
Mirror carp & 30000 & 24000 & 25000 \\
Leather carp & 22400 & 12500 & 7500 \\
\hline Total income & $\mathbf{1 5 4 6 0 0}$ & $\mathbf{1 2 0 5 0 0}$ & $\mathbf{1 0 7 5 0 0}$ \\
\hline
\end{tabular}

\subsubsection{Cost benefit ratio}

Cost benefit ratio $=\frac{\text { Total benefit }}{\text { Operating cost }}$

Cost benefit ratio in January $=154600 / 100555=1.54$

Cost benefit ratio in February $=120500 / 91550=1.32$

Cost benefit ratio in March $=107500 / 87000=1.23$

Table 8. Net profit.

\begin{tabular}{lll}
\hline Month & Total income (BDT) - Total cost (BDT) & Net profit (BDT) \\
\hline January & $154600-104688.33$ & 49911.67 \\
February & $120500-95683.33$ & 24816.67 \\
March & $107500-91133.33$ & 16366.67 \\
\hline \multicolumn{2}{c}{ Grand total net profit } & $\mathbf{9 1 0 9 5 . 0 1}$ \\
\hline
\end{tabular}

\section{Discussion}

During the present study it was observed that the water temperature was $19.0-26.0^{\circ} \mathrm{C}$. Yeasmin (2015) accomplished induced breeding of common carps at the $27-29^{\circ} \mathrm{C}$. Hakim and Gamal (2009) stated that the growth of larvae increased at the optimum temperature from $27-30^{\circ} \mathrm{C}$ in common carp which was relevant to that of above findings.

The present study showed that mean dissolve oxygen (DO) of brood ponds and hatching jars were 5.57 and 5.45 $\mathrm{mg} / \mathrm{l}$, respectively. The mean $\mathrm{pH}$ of brood ponds and hatching jars were 7.34 and 7.16, respectively. Yeasmin (2015) reported the average DO and $\mathrm{pH}$ were 5.03 and 7.23, respectively which was close to that of the present study. Jahan (2015) stated the transparency was $18-25 \mathrm{~cm}$ in the brood ponds. In the study it was observed that the transparency was $14-18 \mathrm{~cm}$ in the brood ponds.

Brood fish used in the present experiment were maintained in the farm providing formulated feed which proximate composition was analyzed as protein $27.76 \%$, lipid $4.9 \%$, carbohydrate $18.62 \%$, ash $11.31 \%$, moisture $31.01 \%$ and fiber $6.4 \%$ which were more or less similar to the findings of Yeasmin (2015) who reported that diets containing protein $22.5 \%$, lipid $14.5 \%$, ash $5.63 \%$, moisture $7.5 \%$ and also close to the result 
of Jahan (2015) who reported that formulated feed composed of protein $11.94 \%$, lipid $9.44 \%$, carbohydrate $9.03 \%$, ash $4.1 \%$, moisture $61.29 \%$ and fiber $4.2 \%$.

The price of Ma-Fatema fish hatchery produced spawn/larvae were $3000 \mathrm{BDT} / \mathrm{kg}$ for scale carp, 2500-3000 BDT $/ \mathrm{kg}$ for mirror carp and 2500-2800 BDT/kg for leather carp during the study period. The price of spawn/ larvae was high in early breeding season but the price was low in late season which was close to the findings of Sharif and Asif (2015) who studied on present status of fish hatchlings and fry production management in greater Jessore and stated that the price of common carp spawn/larvae was 1800-2200 BDT/kg. Shaha (2013) reported that cost benefit ratio was 1.24-1.98 and the net profits were BDT 42,744.445-1, 89,794.445 during the whole experimental period. In the present study it was observed that cost benefit ratio was $1.54,1.32,1.23$ and net profits were 49911.67, 24816.67 and 16366.67, respectively in January, February and March.

\section{Conclusions}

The demanded protein requirement will be possibly fulfill through aquaculture. Management of broods includes collection of healthy breeders, rearing them by providing quality feed and keeping physico-chemical parameters under optimum condition for proper growth and maturation. Optimization of stocking density, feeding management and maintaining water quality parameters are necessary in the production of spawn/larvae. Costbenefit ratio of hatchery in common carp production was satisfactory by the hatchery owners.

\section{Conflict of interest}

None to declare.

\section{References}

Akhter S, 2007. Induced breeding of Vietnam koi using PG and ovaprim at Tasty Fish And Feed Industries Limited, MS thesis, Department of Fisheries Management, Bangladesh Agricultural University, Mymensingh.

AOAC, 1980. Official Methods of Analysis, Association of Official Analytical Chemists, $13^{\text {th }}$ edition, Washington DC, USA. p. 1018.

Boyd CE, 1990. Water quality in ponds for aquaculture. Auburn University, Alabama Agricultural Experiment Station. Science. p. 482.

DoF, 2014. Department of Fisheries, Ministry of Fisheries and Livestock, Annual Report 2014-2015, Bangladesh. p. 111.

Hakim AE and EE Gamal, 2009. Effect of temperature on hatching and larval development and mucin secretion in common carp, Cyprinus carpio (Linnaeus, 1758). Global Veterinaria, 3: 80-90.

Jahan I, 2015. Induced breeding of indigenous carps (Labeo rohita, Calla catla, Cirrhinus cirrhosus) using a synthetic flash hormone at a Government Fish hatchery, Maskanda, Mymensingh, MS thesis, Department of Aquaculture, Bangladesh Agricultural University, Mymensingh.

Parra JEG and B Baldisserotto, 2007. Effect of water $\mathrm{pH}$ and hardness on sunival and growth of freshwater teleports. In: B Baldisserotto, JM Mancera and BG Kapoor (Editors), Fish osmoregulation. Science Publishers, Enfield, United Kingdom.

Samad MA, MT Hossain and BMS Rahman, 2013. Present Status of Broodstock Management at Carp Hatcheries in Jessore. J. of Bangladesh Agricultural University, 11:349-358.

Shaha PR, 2013. A study on induced breeding and cost- benefit analysis of three exotic carps. MS thesis, Department of Fisheries Management, Bangladesh Agricultural University, Mymensingh.

Sharif BMN and AA Asif, 2015. Present status of fish hatchlings and fry production management in greater Jessore, Bangladesh. International J. of Fisheries and Aquatic Studies, 2: 123-127.

Webber H and PF Riordan, 1976. Criteria for candidate species for aquaculture. p. 23.

Wilkie MP and CM Wood, 1994. The effect of extremely alkaline water (pH 9.5) on Rainbow Trout Gill Function and Morphology. J. of Fish Biology, 45: 87-98.

Yeasmin SM, 2015. Broodstock management and induced breeding of common carp (Cyprinus carpio var. Linnaeus, 1758) among three hatcheries at Jessore, MS thesis, Department of Fisheries and Marine Bioscience, Jessore University of Science and Technology, Jessore.

Zweig RD, Morton JD and MM Stewart, 1999. Source water quality for aquaculture: a guide for assessment. Environmentally and socially sustainable development series, Rural development, World Bank (USA). p. 72. 